\title{
Environmental Impact Assessment Handbook
}


Downloaded by [] on [26/04/23]. Copyright @ ICE Publishing, all rights reserved. 


\section{Environmental Impact Assessment Handbook}

\section{A practical guide for planners, developers and communities}

Third edition

\section{Barbara Carroll \\ Director, Enfusion}

\section{Josh Fothergill}

Founder and Director, Fothergill Training and Consulting

\section{Jo Murphy}

CEO, Fothergill Training and Consulting

\section{Trevor Turpin}

Environmentalist and Writer 
Published by ICE Publishing, One Great George Street, Westminster, London SW1P 3AA

Full details of ICE Publishing representatives and distributors can be found at: www.icebookshop.com/bookshop_contact.asp

\section{Other titles by ICE Publishing:}

Contaminated Land Guidance, Third edition

Jo Strange, Nick Langdon and Alex Large ISBN: 978-0-7277-6106-4

Sustainable Water

Charles Ainger and Richard Fenner (eds.) ISBN: 978-0-7277-5773-9

Environmental Geotechnics in Practice: Introduction and case studies

Robert W. Sarsby ISBN: 978-0-7277-6363-1

www.icebookshop.com

A catalogue record for this book is available from the British Library

ISBN 978-0-7277-6141-5

(C) Thomas Telford Limited 2020

ICE Publishing is a division of Thomas Telford Ltd, a wholly-owned subsidiary of the Institution of Civil Engineers (ICE).

All rights, including translation, reserved. Except as permitted by the Copyright, Designs and Patents Act 1988, no part of this publication may be reproduced, stored in a retrieval system or transmitted in any form or by any means, electronic, mechanical, photocopying or otherwise, without the prior written permission of the Publisher, ICE Publishing, One Great George Street, Westminster, London SW1P 3AA.

This book is published on the understanding that the authors are solely responsible for the statements made and opinions expressed in it and that its publication does not necessarily imply that such statements and/or opinions are or reflect the views or opinions of the publishers.

While every effort has been made to ensure that the statements made and the opinions expressed in this publication provide a safe and accurate guide, no liability or responsibility can be accepted in this respect by the authors or publishers.

Although Jo Murphy currently works for the Environment Agency, the views and opinions expressed in this book do not necessarily reflect those of the Environment Agency.

While every reasonable effort has been undertaken by the author and the publisher to acknowledge copyright on material reproduced, if there has been an oversight please contact the publisher and we will endeavour to correct this upon a reprint.

Cover photo: Aerial view of Stratford and Queen Elizabeth Olympic Park.

Contributor: Loop Images Ltd / Alamy Stock Photo

Commissioning Editor: Michael Fenton

Development Editor: Audra Taylor

Production Editor: Madhubanti Bhattacharyya

Marketing Specialist: April Asta Brodie

Typeset by Academic + Technical, Bristol

Index created by Annette Musker

Printed and bound in Great Britain by Bell and Bain, Glasgow 


\section{Contents}

Foreword to the first edition (2002)

Foreword to the second edition (2009)

Foreword to this edition

Preface

Acknowledgements

About the authors

Abbreviations

01

\section{EIA in context}

1.1. What is EIA?

1.2. EIA's purpose and benefits

1.3. Proportionate EIA

1.4. Key EIA terminology

1.5. The process of EIA

1.6. EIA and the law - legal basis, key concepts and challenge

1.7. Key stakeholders in EIA

1.8. Knowledge, skills and behaviours for effective EIA

1.9. The future - EIA, Brexit and beyond

References

Case law

Legislation

2.2. EIA screening - determining the need for an assessment

03

EIA pre-submission - the assessment and environmental statement 31

3.1. Getting the ElA started 31

3.2. Focusing the EIA (scoping) 34

3.3. Baseline studies 41

3.4. Assessment and evaluating significance 45

3.5. Enhancement, mitigation and monitoring 48

3.6. The environmental statement 56

References 58

Legislation $\quad 59$

$04 \ldots \ldots \ldots \ldots \ldots \ldots \ldots \ldots \ldots \ldots \ldots \ldots \ldots$ EIA and consenting - consultation, examination and decision 61

4.1. Introduction 61

4.2. Overview of EIA post-submission 62

4.3. Consultation and further information 64

4.4. Examination and reasoned significant effects 66

4.5. Committee report 68

4.6. Decision notice 68

$\begin{array}{lr}\text { References } & 69\end{array}$

Legislation $\quad 69$

$05 \ldots \ldots \ldots \ldots \ldots \ldots \ldots \ldots \ldots \ldots$ Integrating EIA with ... design, delivery and other assessments 71

5.1. Integrating EIA with ... an introduction 71

$\begin{array}{ll}\text { 5.2. Sustainability and sustainable development } & 72\end{array}$

5.3. Strategic assessment 73

5.4. Project planning and design 76

5.5. Habitats Regulations assessments (HRAs) 77

5.6. Water Framework Directive assessments 81

5.7. Equality assessment 83

5.8. Natural capital, valuing the environment, ecosystem services and the net
gain principle

5.9. CEEQUAL 87 
5.10. EIA's role post-consent: delivery 89

5.11. Conclusion 91

References $\quad 92$

Case law 95

Legislation $\quad 95$

$06 \ldots \ldots \ldots \ldots \ldots \ldots \ldots \ldots \ldots \ldots \ldots \ldots \ldots \ldots$ Non-planning EIA regimes $97 \ldots$

6.1. Introduction 97

6.2. Infrastructure consented via Acts of Parliament 97

6.3. Nationally significant infrastructure 98

6.4. EIA for highways and transport 98

6.5. EIA and flood risk management - land drainage $\quad 100$

6.6. Marine works 100

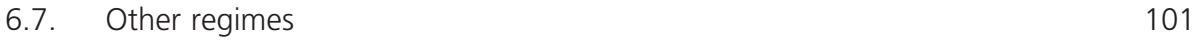

References $\quad 104$

Legislation 105

$07 \ldots \ldots \ldots \ldots \ldots \ldots \ldots \ldots \ldots \ldots \ldots \ldots$ Environmental topics $107 \ldots$

$\begin{array}{ll}\text { 7.1. Introduction } & 107\end{array}$

7.2. Human health 108

7.3. Biodiversity (ecology, flora and fauna) 114

7.4. Soil 119

7.5. Water 123

7.6. Air quality 128

7.7. Climate change 132

7.8. Cultural heritage 136

7.9. Landscape and visual impact 141

7.10. Noise 146

$\begin{array}{ll}\text { 7.11. Agricultural land } & 151\end{array}$

7.12. Material assets 152

$\begin{array}{ll}\text { 7.13. Transport } & 154\end{array}$

7.14. Major accidents and disasters $\quad 155$

References $\quad 157$

Legislation $\quad 161$

Appendix $1 \ldots \ldots \ldots \ldots \ldots \ldots \ldots$ Links to key consultees, organisations and stakeholders across the UK'S EIA regimes

UK-wide EIA bodies $\quad 163$

England $\quad 165$

Scotland 166

$\begin{array}{ll}\text { Northern Ireland } & 167\end{array}$

$\begin{array}{ll}\text { Wales } & 167\end{array}$

Appendix $2 \ldots \ldots \ldots \ldots \ldots \ldots \ldots$ Overview of UK EIA guidance 169

UK government $\quad 169$

European Commission guidance 169

EIA practice guidance $\quad 170$

EIA topic guidance $\quad 170$

Index 173 
Foreword to the first edition (2002)
Since its birth in the United States just over 30 years ago, a huge literature on environmental impact assessment (EIA), both within the UK and the rest of the world, has been spawned. As one who has contributed his fair share to this, I can confidently say that this practical handbook is unique. It is not academic, as so much of the literature tends to be (mea culpa), yet it is likely to prove very useful not only to students but also to academics seeking to familiarise themselves with a new field. It is not procedural, yet it explains how the EIA process works and refers the reader gently to the appropriate chapter and verse. It is not theoretical, but it describes many of the approaches and methods used in EIA. It is not an activist's charter, yet it provides the ammunition to challenge an environmental statement. Rather, it is an approachable and practical handbook, with numerous illustrated explanations and examples, written from the practitioner's perspective.

Over the dozen or so years we have had EIA in the UK, it has become part of our everyday life. It is increasingly common to hear on the news that the results of an EIA have revealed that some impact or other is likely to be problematic or that protesters have demanded an EIA before a development is allowed to proceed. The concept of environmental assessment is expanding from the evaluation of projects to the environmental appraisal of plans and policies. We all need an accessible, practical explanation of EIA, whether we are developers, consultants, central or local authority officers, environmental regulators, environmental activists, local residents, students or academics. This practical handbook is it!

\section{Christopher Wood}

EIA Centre, School of Planning and Landscape, University of Manchester, 2002 
Downloaded by [] on [26/04/23]. Copyright @ ICE Publishing, all rights reserved. 
Foreword to the second edition (2009)
Since this book was first published in 2002, the world of environmental impact assessment (EIA) has continued to move forward and adapt to meet the current needs of decision-makers. Changing demands have brought forward new demands for the incorporation of climate change, health impact assessment, social deprivation, sustainable development, technology assessment and the greater demonstration of how consideration of environmental aspects has influenced final designs and development structures. This process has not been made any easier for the practitioner by increasing legal and public challenge and the negative stance to EIA adopted by the Barker Review amongst others. Finally, EIA practitioners now have to ride two horses, with the statutory introduction of strategic environmental assessment (SEA) demanding the application of new skill sets and mental gymnastics by those who attempt to operate in both fields of specialism. All this plus corporate governance, liability insurance and public participation!

The original book quickly earned its place in the bookcase of non-specialist and students alike and was soon reprinted to meet demand. It was especially well received by engineers and planners as well as EIA practitioners. From experience, in my work as the manager of the Environment Agency's National Environmental Assessment Service we have found it useful for training purposes and for the insight many of its sections bring to key areas of practice.

However, with more experience, legislation and the sheer complexity of some EIA demands, it became apparent that an update was necessary. This new edition builds on the format and information of the first, updating broad legislative principles and including a new section on SEA, of which the authors have considerable practical experience.

It is this translation of practical experience into an easy to read and follow style that made the first edition so well received, and I welcome its successor!

Ross Marshall

Manager, National Environmental Assessment Service, Environment Agency 
Downloaded by [] on [26/04/23]. Copyright @ ICE Publishing, all rights reserved. 


\section{Foreword to this edition}

Environmental impact assessment (EIA) has been with us for nearly half a century, and there can be no doubt that it has come a long way since its original inception through the 1969/1970 US National Environmental Policy Act. Virtually all countries globally now have some formal EIA requirements in place. Despite a substantial amount of criticism over the years, EIA has stayed with us and has matured, even if remaining unpopular with some, including, on the one hand, developers who think it's too expensive and, on the other, environmentalists who claim it's ineffective in stopping environmentally harmful projects. It's probably this peculiar position of being 'caught in the middle' that has made it resilient. Also, all attempts to develop alternative tools to EIA have resulted in propositions that look remarkably similar to what we already have, suggesting that at the very heart, there is nothing wrong with its underlying approach.

This is the third edition of the EIA Handbook, which is now coming of age. It is fitting at a time of fundamental - economic, social and environmental - change. An important question arising is how a decision support tool based on instrumental rationality can survive the current post-truth era in which it is not evidence that appears to sway people's opinions but rather beliefs. On the one hand, it's by providing evidence for its effectiveness. On the other, it's by offering hands-on and - as far as possible - simple advice for how to do it. It is here where the EIA Handbook is at its best and indispensable, providing clear and easy to understand instructions. In nearly 18 years, the EIA Handbook has become one of the few definitive books in the UK for practitioners (engineers, planners and others) as well as for students. This revision ensures it will continue to be in this position for some time to come.

\section{Professor Thomas B. Fischer}

Director, Environmental Assessment and Management Research Centre, School of Environmental Sciences, University of Liverpool, UK

Extraordinary Professor, Research Unit for Environmental Sciences and Management, North West University (Potchefstroom Campus), South Africa 
Downloaded by [] on [26/04/23]. Copyright @ ICE Publishing, all rights reserved. 


\title{
Preface
}

\begin{abstract}
About this practical handbook
The aim of this handbook is to provide practical guidance on environmental impact assessment (EIA). EIA is a systematic procedure for ensuring that the likely significant effects of new development on the environment are taken into account in deciding whether the proposed project should go ahead or not. EIA is explained here in accordance with the requirements and format of the UK Town and Country Planning (Environmental Impact Assessment) Regulations 2017 (SI 2017/571) as amended (the EIA Regulations). The assessment of effects on the environment, the production of the environmental statement (ES) to present these findings, and the consenting authority's consultation, examination and consent decision, all make up the EIA process.
\end{abstract}

This third edition provides a complete review and renewal of the text building on the practical purpose of the handbook, while placing greater emphasis on details about the core steps in the screening, scoping, assessment, ES write-up, and post-submission consultation and examination than the previous editions. It also includes a new separate chapter on how EIA can be effectively linked with many other processes and assessments that have emerged since the UK's EIA Regulations were introduced back in 1988 .

This guidance is written for planners, designers and developers who need sufficient introduction to EIA to know what needs to be prepared by whom and by when. It will also be useful for project managers, students and community groups. The handbook approach has been designed based on good practice, making its guidance readily useful as a reference for EIA practitioners and environmental specialists.

\section{The objectives of the EIA Handbook}

v To present the requirements of EIA according to the UK EIA Regulations in a readily usable and practical way.

Legislation and guidance is generally given for England. The relevant legislation and guidance for Wales, Scotland, Northern Ireland or other countries should always be consulted.

- To inspire and share experience towards good EIA practice by a practical handbook format illustrated with advice, reference to further information, practice principles and case studies.

- To inform and guide the use of EIA early and effectively in the development design and land use planning processes.

- To demonstrate the advantages of effective and proportionate EIA practice, including linkages to other processes, to facilitate better-informed planning decisions.

\section{Who the EIA Handbook is written for}

- Planners of local authorities who need to advise on the requirements for EIA and receive planning applications accompanied by ESs. It will also be useful for other officers dealing with conservation, transport and environmental health issues who will be consulted on such planning applications.

- Professionals regulating projects subject to legislation other than spatial and development control planning.

- Developers who need to understand EIA prior to early discussions with local authorities and appointment of specialist consultants.

- Designers, architects, engineers, surveyors, planners and other professionals working as project managers on development proposals who need to understand why, when and how to include EIA in their projects.

- Environmental topic specialists, as an easy reference and to understand the requirements of other specialisms and the context within the EIA process.

- The statutory consultees in the EIA and spatial and development control planning processes who need to understand their role. 
- The community sector, which could make use of this guide to assist its understanding of, and participation in, EIA and the development planning process.

- Students of environmental and sustainability courses as well as those students on engineering, architecture, planning and related courses who study EIA as a core or subsidiary subject.

- Users primarily in the UK; however, the principles and practice have world-wide applications. 


\section{Acknowledgements}

As we acknowledged in the first and second editions of this handbook, in a book of this nature, based as it is on practical experience, gratitude is owed to a wide range of people whose approach and decisions have guided environmental impact assessments (EIAs) in particular directions. These include clients, developers, academics, planning authority officers, regulators and practitioners - especially those that have poured time and effort into volunteering to improve EIA through the Institute of Environmental Management and Assessment (IEMA) and other institutes over the years. To all of them we would like to express our thanks for contributing to what continues to be an inspiring and challenging field ... we are all still learning.

For this third edition of the handbook, specific support in drafting particular sections and reviewing content have been made by the following

- EIA legal concepts - Stephen Tromans QC and Richard Wald (39 Essex Chambers)

- health - Ryngan Pyper and Ben Cave (Ben Cave Associates)

- biodiversity - Jo Treweek (Treweek Environmental Consultants) and Bob Edmonds (SLR Consulting)

noil and agricultural land - Rob Askew (Askew Land + Soil), with a review from Julie Holloway and Gill Shaw (Natural England)

- water - Will McBain (Arup), with assistance from Tom Styles (Arup)

- air quality - Duncan Laxen and Penny Wilson (Air Quality Consultants)

- climate change - Joanna Wright (LUC)

- cultural heritage - Robert Sutton (Cotswold Archaeology)

- landscape and visual impact - Julian Francis (Environment Agency)

noise - Graham Parry (ACCON UK)

naterial assets - Steve Pearce and Nigel Pilkington (AECOM), with initial input from David Smith (AECOM)

- traffic - Chris Ferrary (Temple Group)

- major accidents and disasters - B. Emberton (Arup).

To all of them we express our sincere thanks for their interest, expertise and support.

Thanks to those who helped in the preparation of the first and second editions of the handbook, and to those book reviewers in journals who provided useful constructive comments. In all cases, however, errors and omissions remain the responsibility of the authors.

Thanks are also due to Jess Ager (Environment Agency), Tom Clancy (Highways England), Ian Nicholson (BRE) and to many others who have helped us along the way. Finally, we must thank our development editor, Michael Fenton of ICE Publishing, for his patience, flexibility and persistence.

Except where noted, photographs and illustrations are either those of the authors or from the libraries of Nicholas Pearson Associates and Enfusion, for which permission to publish is gratefully acknowledged. 
Downloaded by [] on [26/04/23]. Copyright @ ICE Publishing, all rights reserved. 


\section{About the authors}

Barbara Carroll BSc(Hons) MSc CEnv FIEMA

A chartered environmentalist and planner with wide practical and research experience in environmental assessment and sustainable development studies. She is the founder of Enfusion, creative specialists in assessment processes to inform decision-making. Barbara has developed and applied methods of strategic environmental assessment and sustainability appraisal for over 25 years. She was the Visiting Professor of Sustainable Development at the University of Glasgow and a postgraduate tutor in planning and policy at the University of Bath.

\section{Josh Fothergill BSc(Hons) MSc CEnv FIEMA}

A Fellow of the Institute of Environmental Management and Assessment (IEMA) and a chartered environmentalist, he has significant policy, practice and capacity-building experience across environmental impact assessment (EIA), the circular economy and sustainability skills. He is the founder of Fothergill Training and Consulting (FothergillTC), tackling complex challenges by untapping the potential of integrating sustainability with organisational purpose. Josh authored/co-authored the majority of UK EIA practice guidance over the last decade, developed the UK's Proportionate EIA Strategy, and created IEMA's internationally award-winning EIA Quality Mark scheme, launched in 2011.

Jo Murphy BSc(Hons) MSc PGCert(Business Admin) CEnv FIEMA MITOL MCMI A chartered environmentalist, Fellow of IEMA and the Institute of Training and Occupational Learning, she is the chief executive of FothergillTC, providing strategic direction and capacity-building initiatives. Jo is an associate academic of the University of Derby Online, developing EIA and sustainable-business MSc modules and postgraduate tutoring. A member of IEMA's professional standards committee and previously on its council, she has spent nearly 20 years providing technical and competency leadership across impact assessment and sustainability for the Environment Agency.

\section{Trevor Turpin BSc(Hons), BA(Open) MSc MA PhD}

An environmentalist and social scientist, Trevor has over 45 years' practical experience in central and local government, industry and at Nicholas Pearson Associates; he has coordinated EIAs in the UK and overseas since the mid-1980s for all development types. He was the Associate Director of Studies at the University of Bath MSc in Integrated Environmental Management, and has lectured at universities in the UK and USA. He was elected to the council of the Institute of Environmental Assessment to represent corporate members, and served on committees of its successor, IEMA. He encourages creative mitigation and seeks to establish a sense of place in EIA projects. 
Downloaded by [] on [26/04/23]. Copyright @ ICE Publishing, all rights reserved. 


\begin{tabular}{|c|c|}
\hline AA & appropriate assessment \\
\hline ALC & Agricultural Land Classification \\
\hline AONB & Area of Outstanding Natural Beauty \\
\hline AQMA & Air Quality Management Area \\
\hline BEIS & Department for Business, Energy and Industrial Strategy \\
\hline BMV & best and most versatile \\
\hline $\mathrm{BNG}$ & biodiversity net gain \\
\hline BREEAM & $\begin{array}{l}\text { Building Research Establishment Environmental Assessment } \\
\text { Methodology }\end{array}$ \\
\hline $\mathrm{BS}$ & British Standard \\
\hline BSSS & British Society of Soil Science \\
\hline CEA & cumulative effects assessment \\
\hline CEEQUAL & Civil Engineering Environmental Quality Assessment \\
\hline CIEEM & Chartered Institute for Ecology and Environmental Management \\
\hline CIfA & Chartered Institute for Archaeologists \\
\hline CJEU & European Court of Justice \\
\hline DAERA & $\begin{array}{l}\text { Department of Agriculture, Environment and Rural Affairs } \\
\text { (Northern Ireland) }\end{array}$ \\
\hline $\mathrm{DCO}$ & development consent order \\
\hline Defra & Department for Environment, Food and Rural Affairs \\
\hline DMRB & Design Manual for Roads and Bridges \\
\hline EcIA & ecological impact assessment \\
\hline EIA & environmental impact assessment \\
\hline ELC & European Landscape Convention \\
\hline EMP & environmental management plan \\
\hline ES & environmental statement \\
\hline ESIA & environmental and social impact assessment \\
\hline FCS & Forestry Commission Scotland \\
\hline GHG & greenhouse gas \\
\hline GLVIA3 & Guidelines for Landscape and Visual Impact Assessment, 3rd edition \\
\hline HRA & Habitats Regulation assessment \\
\hline IAP2 & International Association for Public Participation \\
\hline IAQM & Institute of Air Quality Management \\
\hline IEMA & Institute of Environmental Management and Assessment \\
\hline ISO & International Standards Organization \\
\hline LCA & landscape character assessment \\
\hline LLFA & lead local flood authority \\
\hline LOAEL & lowest observed adverse effect level \\
\hline LPA & local planning authority \\
\hline LSE & likely significant effect \\
\hline LVIA & landscape and visual impact assessment \\
\hline MHCLG & Ministry of Housing, Communities and Local Government \\
\hline MMO & Marine Management Organisation \\
\hline $\mathrm{NCC}$ & Natural Capital Committee \\
\hline NGO & non-governmental organisation \\
\hline NPPF & National Planning Policy Framework \\
\hline NPS & national policy statement \\
\hline NSIPs & Nationally Significant Infrastructure Projects \\
\hline NTS & non-technical summary \\
\hline PCP Act & Planning and Compulsory Purchase Act \\
\hline PEA & preliminary ecological appraisal \\
\hline PINS & Planning Inspectorate \\
\hline RBMP & river basin management plan \\
\hline RSPB & Royal Society for the Protection of Birds \\
\hline SAC & Special Area of Conservation \\
\hline SEA & strategic environmental assessment \\
\hline SOAEL & significant observed adverse effect level \\
\hline SPA & Special Protection Area \\
\hline SSSI & Site of Special Scientific Interest \\
\hline
\end{tabular}




$\begin{array}{ll}\text { TA } & \text { transport assessment } \\ \text { TCP } & \text { Town and Country Planning } \\ \text { TS } & \text { transport statement } \\ \text { TWA } & \text { Transport Works Act } 1992 \text { (as amended) } \\ \text { TWAO } & \text { Transport and Works Act order } \\ \text { UN } & \text { United Nations } \\ \text { UNECE } & \text { United Nations Economic Commission for Europe } \\ \text { VEC } & \text { valued ecosystem(/environmental) component } \\ \text { WFD } & \text { Water Framework Directive } \\ \text { WHO } & \text { World Health Organization } \\ \text { WRAP } & \text { Waste Resource Action Programme } \\ \text { ZTV } & \text { zone of theoretical visibility }\end{array}$

